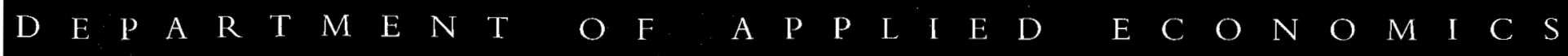

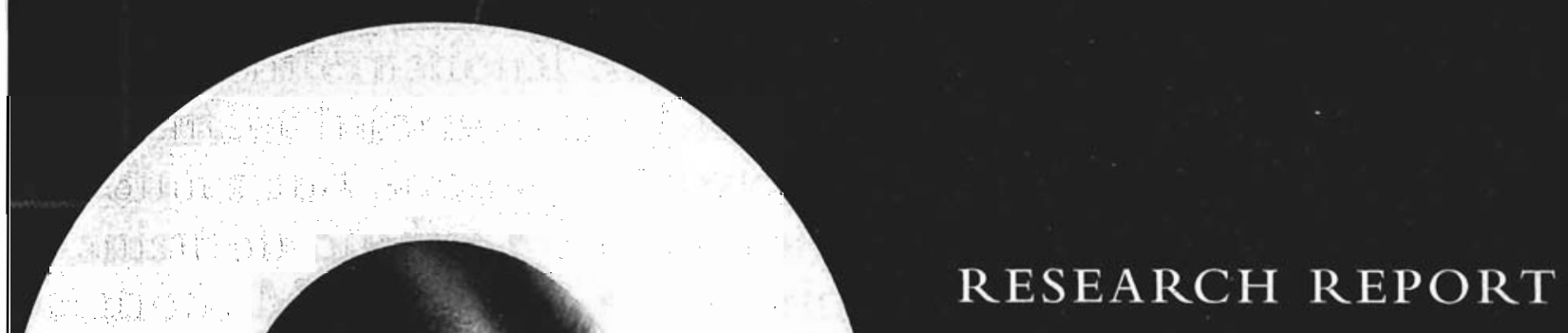

THE ROLE OF RISK MANAGEMENT AND GOVERNANCE IN DETERMINING AUDIT DEMAND

W. ROBERT KNECHEL • MARLEEN WILLEKENS

OR 0463 


\title{
THE ROLE OF RISK MANAGEMENT AND GOVERNANCE IN DETERMINING AUDIT DEMAND
}

\author{
W. Robert Knechel \\ University of Florida \\ Marleen Willekens \\ Catholic University of Leuven
}

Version December 2004

We thank for constructive comments the participants in the University of Tilburg Accounting conference (October 2004), and the participants in the accounting and finance workshops at Lancaster University and the University of Florida. 


\title{
TTHE ROLE OF RISK MANAGEMENT AND GOVERNANCE IN DETERMINING AUDIT DEMAND
}

\begin{abstract}
Most prior research into audit fees has been based on a theoretical model which treats audit fees as the by-product of a production function (Simunic, 1980) hereby ignoring potential demand forces that may drive the level of the audit fee. In such a production-oriented view of auditing, alternative control mechanisms (such as internal auditing and corporate governance) are hypothesized to be substitutes for external auditing, and hence more of one control mechanism is expected to be negatively associated with the level of external auditing, and hence the audit fee.

In this paper we examine the impact of risks and controls in the determination of audit fees. Inspired by prior 'anomalous' results, we take a different perspective by focusing on some omitted demand factors that may affect the level of the audit fee. Based on Hay and Knechel (2004), we argue that when multiple stakeholders are included in the analysis a positive association between various risk management / control mechanisms and external audit demand is a very likely outcome, which is attributable to sharing of control costs between stakeholders and positive control externalities amongst stakeholders.

Using data collected from a sample of listed companies in Belgium, we consider both disclosures about risk and risk management and actual decisions about corporate governance to examine whether audit fees are higher when hypothesized demand forces exist. Consistent with our expectations, our results indicate that audit fees are higher when a company has an audit committee, discloses a relatively high level of financial risk management, and has a larger proportion of independent Board Members. Audit fees are lower when a company discloses a relatively high level of compliance risk management. The latter result indicates that controls are only complementary as long as they are voluntary, as mandated controls act as substitutes for non-mandated controls.
\end{abstract}




\section{THE ROLE OF RISK MANAGEMENT AND GOVERNANCE IN DETERMINING AUDIT DEMAND}

An extensive body of literature has developed related to the level and nature of audit fees in organizations. The original seminal work by Simunic (1980) spawned an expanding body of literature that has examined a large number of possible drivers of audit fees. ${ }^{1}$ Numerous general conclusions can be drawn from this literature, e.g., audit fees are influenced by factors related to the size of the organization (total assets), complexity (subsidiaries or foreign operations), inherent risk (receivables and inventory), and litigation risk (levels of debt, leverage). Other research has identified a number of factors where the effect on audit fees is either inconsistent or counter to expectations. For example, research linking internal auditing to external auditing has resulted in some studies observing a positive association (Anderson and Zeghal, 1994) and others showing a negative association (Wallace, 1984). Still other research has indicated that audit fees are positively related to the quality of corporate governance (Carcello et al 2002; O'Sullivan, 2000; Hay and Knechel, 2004), which runs counter to intuition since good corporate governance would improve the control environment of an organization and could be expected to lead to lower audit fees.

One possible explanation for these anomalies and inconsistencies is that most research into audit fees has been based on a theoretical model which treats audit fees as the by-product of a production function (Simunic, 1980). To justify use of a production view of the audit, some strong assumptions are needed, e.g., (1) the market for audit services is competitive and (2) the level of assurance delivered is constant within a firm, implying that audit fees are a function of cost. Hay, Knechel and Wong (2004) argue that these assumptions may not be robust to the actual market for audit services and the anomalies and inconsistencies may be due to omitted

\footnotetext{
${ }^{1}$ See Hay, Knechel and Wong (2004) for an overview of the literature on audit fees.
} 
demand factors and the endogeneity of decisions about alternative controls. If the market for audit services is not generally competitive or levels of assurance vary across engagements, differential demand forces can lead to variations in audit fees that are not production related.

To illustrate, consider the link between corporate governance and auditing. In a production view, good corporate governance-such as the existence of independent Board members - should improve the control environment and reduce the need for external auditing, leading to a reduction in audit fees. However, Hay and Knechel (2004) argue that a demand effect may lead to the opposite result: independent directors may demand more auditing in order to fulfill their responsibilities and protect their own reputations against questionable financial reporting decisions made by management. Specifically, Hay and Knechel (2004) argue that the demand for auditing is a function of the set of risks faced by individual stakeholders in an organization (management, shareholders, creditors, etc.) and the set of control mechanisms available for mitigating those risks. Because individual decisions about control processes and procedures may shift benefits and costs across groups of stakeholders, the net investment in auditing may increase when multiple stakeholders become involved in corporate governance decisions.

In this paper, we examine the role of risks and controls in the determination of audit fees. Using data collected from a sample of companies in Belgium, we consider both disclosures about risk and risk management and actual decisions about corporate governance to examine whether audit fees are higher when hypothesized demand forces exist. Consistent with our expectations, our results indicate that audit fees are higher when a company has an audit committee, discloses a relatively high level of financial risk management, and has a larger proportion of independent Board Members. Audit fees are lower when a company discloses a relatively high level of 
compliance risk management. The remainder of the paper is organized as follows: In the first section we describe a theoretical framework for analyzing the demand for audit services. In the second section, we discuss prior research and specify our hypotheses. The third section describes our research methodology, the variables used in the study and the source of the date. This section is followed by a presentation of our results. The final section summarizes our results, presents some conclusions and explains the limitations of the paper.

\section{Theoretical Framework for the Demand for Audit Services}

The demand for external assurance services, including a financial statement audit, is presumed to be dependent on the interaction of (1) the set of risks affecting the individual stakeholders of an organization and (2) the set of control mechanisms that are available to reduce the effect of those risks, which will also vary across stakeholders. For empirical purposes, we assume that the demand for auditing is manifested by the audit fee (F), which can be decomposed into (1) a quantity effect (i.e., hours worked during the audit, or q) and (2) a price effect (i.e., fee charged per hour of work, or p). We also assume that there are multiple stakeholders that can endogenously influence the demand for controls affecting an organization, including the audit. Each stakeholder (or group of similar stakeholders) has a set of objectives, some of which will be unique and some that will be shared with other stakeholders. Each stakeholder is assumed to confront their own set of risks and can influence a narrow set of controls which is smaller than the entire set of controls available to the organization as a whole. Since an external audit has extensive externalities that may benefit management, investors, employees, creditors and regulators, it may be a desirable element of the control portfolio for many stakeholders. 
The agency literature suggests that some control mechanisms may be substitutable so that there could be a trade-off among various sources of control available to individual stakeholders, including external assurance (Jensen and Meckling (1976)). The decision problem for an individual stakeholder is to minimize the total cost of managing the risks related to their personal interest in the organization. This view of control choice implies that the decisions of individual stakeholders within the system create an endogenous demand for controls, including external assurance. However, this decision process will be affected by a number of possible constraints, e.g., external imposition of some control mechanisms due to regulation. Individual stakeholders will select a level of control that they can influence based on the net benefit to themselves. These control decisions determine the overall level of control achieved and may reflect either the marginal addition of a specific type of control (e.g., establishing an internal audit function) or the scope of a control (e.g., the amount and types of testing performed by the internal auditor). The nature of control choices maps to the overall level of control for a single stakeholder as illustrated in Figure 1. The optimal selection of an individual's level of control occurs at the point where the marginal costs of losses equals the marginal cost of adding more controls. Thus, for a single stakeholder, the solution implies the trade-off of controls and may, or may not, include external assurance above the minimum level required by exogenous regulation.

$$
<<\text { Insert Figure } 1 \text { about here }>>>
$$

The choice of control level is complicated due to the iterative sequence of decisions made by multiple stakeholders that would condition specific decisions about external assurance. For example, the residual equity shareholders first select internal management (or assign that task to themselves). Then, internal management selects and implements internal control processes. Finally, external stakeholders make decisions about governance and external assurance 
conditional on the previous decisions and pre-existing external restrictions (e.g., regulation or contractual provisions). To reflect this complexity, we add the following observations about the aggregate demand for external assurance:

- Heterogeneity of goals: Each stakeholder has an individual objective function, and related set of risks, that is unique from other stakeholders. This reflects the nature of multiple (potentially competing) stakeholders.

- Span of control: No single stakeholder dominates the selection of the control portfolio, that is, different stakeholders can make different decisions about the control mechanisms they can influence. ${ }^{2}$

- Externality of control benefits: The stakeholder who selects a control mechanism may share the benefits with other stakeholders who are independent of the decision.

- Shared control costs: The stakeholder who selects a control mechanism may not bear the full cost of that control, i.e., the cost of some controls may be born by stakeholders who cannot substantively affect the decision. In the extreme, implementation of a control may be detrimental to some stakeholders.

- Conditionality of decisions: Each stakeholder's decisions are conditional on those made by all other stakeholders.

Using the financial statement audit as an example, we see a general manifestation of these observations by considering just three sets of stakeholders: management, investors and creditors. First, the agency literature has highlighted the potentially conflicting objectives (or risk profiles) of management and shareholders as well as shareholders and creditors. Second, management selects and hires the external auditor subject to approval of the shareholders (represented by the Board of Directors) but creditors may have little say in that decision. However, creditors are able to impose other restrictions (i.e., covenants) to address their own risks. The selection of these control mechanisms may not be beneficial to shareholders, and could be detrimental by limiting the choice space of other stakeholders. Third, all parties

\footnotetext{
${ }^{2}$ For example, only creditors would be in a position to demand debt covenants and restrictions on future debt financing but would probably not be in a position to influence decisions about internal control processes or internal auditing.
} 
presumably benefit to some extent from the conduct of a financial statement audit. Fourth, management generally negotiates the cost of the audit and receives a significant benefit due to the reduction of agency costs, but other stakeholders share the cost. ${ }^{3}$ Finally, both investors and creditors make decisions to protect their own immediate interests conditional on the conduct of the audit.

The multiple stakeholder view of the control choice has a significant impact on the decisions made by each stakeholder and creates the possibility that there is a complementary association among controls when demand is aggregated across stakeholders, even if individual decisions are based on a trade-off (substitution) of controls. Although a full dynamic solution of the decision problem is beyond the scope of this paper, ${ }^{4}$ Figure 2 illustrates how the dynamics of demand might develop. First, consider the curve shift labeled (1). Due to cost sharing, the curve representing the costs of controls would shift downwards to reflect the part of the cost of each control that would be passed to other stakeholders (each level of control costs less). The resulting optimum would reflect a net increase in the level of control selected by an individual stakeholder, and an overall increased investment in controls for the entire organization. ${ }^{5}$

A stakeholder will also take into account decisions made by other stakeholders with differing risk profiles. Now, consider the curve shifts labeled (2). Decisions made by other stakeholders would have the impact of shifting the loss function down due to the externality of benefits received by an individual stakeholder given the level of control implemented by others.

\footnotetext{
${ }^{3}$ In a frictionless contracting arrangement, the cost of the controls may be born entirely by the management as a cost of their signaling behavior. Whether or not such an environment exists in reality is subject to debate but the arguments put forth in this paper are based on the assumption that such contracting situations include frictions that keep all signaling costs from accruing to the signaling party (management).

${ }^{4}$ Solution of the decision problem would most appropriately reflect the implicit game among the individual stakeholders.

${ }^{5}$ The selection of the level of control may also create benefits for other stakeholders not directly implementing the control(s). However, we assume that the benefits accruing to other stakeholders are of the nature of a public good and do not reduce the benefit of risk reduction to the initiating stakeholder.
} 
Also, decisions by others would cause an upward shift in each stakeholder's cost curve due to the sharing of costs of controls selected by others. The net effect would be to partially or completely offset the initial shift in the cost curve (1) The resulting optimum could be either higher or lower than the optimum for the case with no externalities. In Figure 2, we have illustrated the outcome in which the final control portfolio (level of control) is higher than the individual choice situation. In general, if the first order (direct) effect of a selected control level exceeds the offsetting second order (indirect) effects of benefits and costs inherited as a result of decisions by others, then the new optimum would be to the right of the individual optimum, resulting in a net increase in demand for control and assurance by the stakeholder. When demand for control is endogenous and then aggregated across stakeholders, there can be a net increase in the total demand for external assurance.

\section{$\quad<<\quad$ Insert Figure 2 about here $\quad>>>$}

The hypotheses about the sources of control developed in the following sections are based on implications derived from the above analysis and prior research. Prior research has generally argued that there should be a trade-off of sources of control (i.e., more of one leads to less of another), implying that alternative sources of control may have a negative relationship with external assurance. This viewpoint is implicitly based on a single decision-maker scenario. In contrast, the analysis in this paper suggests there may be a complementary relationship among many controls due to the multiple stakeholders in the process and the externalities of costs and benefits of their individual decisions. Such an effect would be manifested as an increase in either audit effort (q), audit prices (p), or both. 


\section{Prior Research and Hypotheses:}

Consistent with the arguments in the previous section and results reported in Hay and Knechel (2004) we hypothesize that audit fees are significantly influenced by risk, internal control and governance.

$\underline{\text { Risk }}$

The argument that the level of risks affects audit fees is well-established in the research literature. Inherent risk, usually as measured by inventory and receivables, has uniformly been found to be positively associated with audit fees (Newton and Ashton, 1989; Stice, 1991). Furthermore, proxies for auditor litigation risk have also been shown to be associated with audit fees, including measures of financial health or leverage (Gist, 1994), profitability (Simunic, 1980), and form of ownership, especially whether a company is publicly traded or not (Hackenbrack and Knechel, 1997). Stakeholders are interested in controlling the risks that are most significant to their own objectives given their relationship to the company. Consequently, consistent with prior research, we specify our first hypothesis:

Hypothesis 1: There is a positive association between the level of risk confronting the stakeholders of a company and the audit fee.

To further refine Hypothesis 1, consider the effect of more external assurance on audit costs. Since the audit fee is equal to $\mathrm{p} \mathrm{x} \mathrm{q,} \mathrm{the} \mathrm{demand} \mathrm{for} \mathrm{more} \mathrm{assurance} \mathrm{that} \mathrm{results} \mathrm{in} \mathrm{a} \mathrm{higher} \mathrm{audit}$ fee may be due to an increased effort level by the auditor (q) and/or changing the labor mix of the audit team so as to utilize more experienced personnel on the engagement (p).

\section{Internal Control and Governance}

The demand for auditing is also expected to be influenced by the portfolio of control mechanisms available to mitigate risk. The agency literature suggests that some control 
mechanisms may be substitutable so that there could be a trade-off among various sources of control available to individual stakeholders, including external assurance (Jensen and Meckling, 1976). However, what is substitutable for a single stakeholder may be complementary when considered across stakeholder groups. The conduct of an audit is likely to benefit all stakeholders associated with an organization that are interested in increased credibility in financial reporting, whether or not they participated in the selection of the auditor (Eilifsen et. al., 2001).

The effect of internal control on audit fees is not clear from previous research since early research that examined the impact of internal control and internal auditing on external audit fees produced mixed results. Studies of internal auditing have found positive (Anderson and Zeghal, 1994; Walker and Casterella, 2000), negative (Wallace, 1984), or no (Gist, 1995; Johnson et. al., 1995) association with audit fees. The few studies that have been able to examine internal measures of internal control have generally found no relationship between the quality of internal control and auditor effort (O'Keefe et. al., 1994; Hackenbrack and Knechel, 1997; Mock and Wright, 1999). However, the theoretical model presented in this paper suggests that when the demand for controls is endogenous, the relationship between audit fees and controls should be positive, leading to our second hypothesis:

Hypothesis 2: There is a positive association between the level of internal control in an organization and its audit fee.

Prior research (Hackenbrack and Knechel, 1997; Blokdijk et. al., 2004) has shown that increased levels of internal control are generally associated with more audit effort by the lower ranks of the audit team. This suggests that the audit consumes more effort from lower priced professionals 
when internal control is good. Consequently, we expect that that the increase in fees will be due to an increase in q.

An exception to Hypothesis 2 occurs when the imposition of specific controls is exogenous to the system. An example of this may occur when internal controls are externally (exogenously) mandated by a regulatory authority. Since mandated controls do not arise from an endogenous demand for control, the imposition of such controls may serve as a constraint on stakeholder decisions across all individuals. In such a case, the relationship between mandated controls and audit fees can be negative as stakeholders balance the external requirement against the endogenous demand for other forms of control. Hay and Knechel (2004) argue that a company that is subject to regulation, thus one that may be more sensitive to compliance risk, will have lower audit fees because the organization must maintain highly reliable internal processes so as to comply with regulatory mandates. This effect is reflected in Hypothesis 2A:

Hypothesis 2A: There is a negative association between the level of mandated internal control in an organization and its audit fee.

Since stakeholders are likely to demand less assurance from auditors when mandated controls are in place, it is likely that the reduced audit fee is due to a reduced level of auditor effort (q) ${ }^{6}$

Numerous studies have reported a positive relationship between the quality of corporate governance and audit fees (Collier and Gregory, 1996; O’Sullivan, 2000; Carcello et al., 2002; Abbott et al., 2003; Hay and Knechel, 2004). ${ }^{7}$ The fact that fees are often higher can not be explained within a production orientation since there is no obvious explanation why an auditor

\footnotetext{
${ }^{6}$ To illustrate the potential impact of mandated controls consider the case of a pharmaceutical company. National regulations usually are quite detailed and complex regarding the design and control of manufacturing processes to assure quality and safety. These controls also have the effect of establishing rigorous control over inventory which reduces many risks associated with the recording and processing of inventory, thus reducing the need for other forms of control such as external assurance. A similar phenomenon is evident in the audits of banks where information technology is quite advanced in order to assure proper handling of multitudes of transactions (Pearson and Trompeter, 1994).

${ }^{7}$ One exception to this patter is a paper by Goddard and Masters (2000) who found no association between formation of an audit committee and audit fees.
} 
should bear more risk or perform more testing when the control environment is otherwise considered to be effective. However, the empirical results are consistent with increased demand for external auditing aggregated across multiple stakeholders. For example, a Board member may be generally concerned about the financial performance and reporting of the organization as directed by current management (i.e., investment and/or information risk), but that Director will also be concerned about his or her personal exposure if management commits fraud or some other scandal erupts related to the organization. Consequently, a Director may be interested in extended audit testing in order to minimize the risk of such scandals that may affect his or her personal reputation (i.e., reputation risk). ${ }^{9}$ The resulting investment in external auditing may exceed that necessary to simply reduce information risk to an acceptable level for other stakeholders. Furthermore, the cost of the audit is most likely to be born by the equity shareholders who may have little say in determining the extent of audit work undertaken (Carcello et al., 2002). This observation leads to our third hypothesis:

Hypothesis 3: There is a positive association between the level of corporate governance in place for an organization and its audit fee. ${ }^{10}$

Again, increased demand for assurance will increase audit fees since the auditor may respond by increasing the effort level (q) or the labor mix of the audit team so as to utilize more experienced personnel (q).

\footnotetext{
${ }^{9}$ For example, see Fama (1980) and Eichenseher and Shields (1985).

${ }^{10}$ Note that governance structures may be mandated (e.g., audit committees) but we do not specify a counter hypothesis to $\mathrm{H} 3$ for mandated governance because such rules generally have the effect of increasing or partitioning the active stakeholders in the system (e.g., adding an audit committee), thus increasing the number of sources of overall demand for audit assurance. The difference between internal control and governance in this regard is based on the observation that process/control participants are generally not in a position to demand more audit assurance, something that Board and Audit Committee members can do.
} 


\section{Research Method, Data and Definition of Variables}

Our approach for analyzing audit fees is based on OLS regression consistent with previous research. For all the analyses reported in this paper, the dependent variable is the natural log of audit fees, i.e., LNFEES. The independent variables used in this paper are summarized in Table 1 and explained below.

\section{$<<<<$ Insert Table 1 about here $\quad>>>>>$}

\section{Measures of Risk and Internal Responses to Risk}

Previous research has identified a number of risk proxies that are associated with audit fees. Hay et. al. (2004) identify over 20 different metrics that could be used as financial proxies for risk, but the two most common and frequently significant are measures of inherent risk and profitability. Consequently, we include the following standard proxies in our analysis to control for the level of risk within an organization:

NETINC Level of net income.

RECTA Ratio of accounts receivable to total assets.

Prior research has often measured profitability as the return on assets or with a dummy variable to indicate a loss. Neither of these metrics were significant in our model, nor did they outperform the explanatory power of net income alone. ${ }^{11}$

In addition to the typical risk proxies, we also use a number of risk and risk management measures that are available for the companies in our data set that are specific to a defined set of risks, and which reflect the organization's own assessment of risk and risk management efforts.

\footnotetext{
${ }^{11}$ We also considered risk variables measuring (1) the ratio of inventory to total assets and (2) the ratio of debt to total assets. These variables were not significant in any of our analyses and have been deleted from the model to preserve degrees of freedom.
} 
Such risk measures may be more accurately calibrated to underlying conditions than the measures that have been used in previous fee research because they reflect company-specific risk information. The risk measures pertain to 6 specific areas of risk that are common to virtually all organizations: financial, compliance, environmental, technology, internal process and change management risks (e.g., see Knechel, 2001). Specifically, we use risk management disclosures made by the company to compute six separate risk management measures:

RISK1 A score from 1 to 5 , scaled by the maximum value in the sample, reflecting the extent of disclosures about management of financial risk.

RISK2 A score from 1 to 5, scaled by the maximum value in the sample, reflecting the extent of disclosures about management of compliance risk.

RISK3 A score from 1 to 5, scaled by the maximum value in the sample, reflecting the extent of disclosures about management of environmental and safety risk.

RISK4 A score from 1 to 5 , scaled by the maximum value in the sample, reflecting the extent of disclosures about management of technology risk.

RISK5 A score from 1 to 5 , scaled by the maximum value in the sample, reflecting the extent of disclosures about management of internal process risk.

RISK6 A score from 1 to 5 , scaled by the maximum value in the sample, reflecting the extent of disclosures about management of change management risk.

The risk management scores were computed by scoring each company's disclosures about risk and risk management on a five point scale. For each company, the annual report was evaluated for information about specific types of risk and related risk management practices. For any given company, a score of five is assigned if the company disclosed all of the following items of information regarding a specific area of risk:

- A general qualitative discussion of the specific type of risk and related risk management practices.

- Current period quantitative risk and risk management information. 
- Prior period quantitative risk and risk management information.

- Future period quantitative risk and risk management information.

- Quantitative benchmarks for the specific type of risk and related risk management practices.

A point is subtracted for each category that is missing for a specific company. We assume that the more sensitive a company is to a specific type of risk, the more extensive and informative its disclosures will be related to that risk and its risk management activities. This sensitivity reflects the joint effect of the existence of the risk and the company's desire to invest resources to mitigate the specific type of risk. Given the potential sharing of costs and benefits of specific control processes, we expect that the disclosure of risk and risk management indicates that the organization is very sensitive to the need to identify and manage those specific stakeholder risks, regardless of who is making decisions about specific controls. Consistent with Hypothesis 2, we expect to find a positive relationship between audit fees and RISK1, RISK4, RISK5 and RISK6. Since RISK2 and RISK3 reflect the impact of external regulation, we expect them to have a significant negative relationship with audit fees, consistent with Hypothesis 2A.

Two other measures of the quality of internal control were extracted from the financial reports of the company:

IA Dummy variable $=1$ if the company has an internal audit department, zero otherwise.

RISKMAN Dummy variable $=1$ if the company uses formal models of risk management as part of internal control, zero otherwise.

In line with Hypothesis 2, we also expect to find a positive relationship between these two measures of internal control and the level of audit fees paid by an organization. 


\section{Governance Variables}

A number of typical measures of the quality of corporate governance and internal control were included in the model for audit fees. Numerous measures of the quality of corporate governance have been suggested and examined in previous research (Carcello et al., 2002; Klein, 2001). Consistent with this previous research we examine the following measures of the quality of corporate governance:

BIG5 Dummy variable $=1$ if audit firm is a Big 5 firm, zero otherwise.

AUDCOM Dummy variable $=1$ if the company has an audit committee, zero otherwise.

NONEX Number of non-executive members of the Board of Directors.

NONEX\% Percentage of the Board of Directors that are considered to be nonexecutive directors.

INDEP Number of independent members of the Board of Directors. ${ }^{12}$

INDEP\% Percentage of the Board of Directors that are considered to be independent.

BODNR Total number of members on the Board of Directors.

CEOCHR Dummy $=1$ if the CEO is also the Chairperson of the Board of Directors, zero otherwise.

Based on Hypothesis 3, we expect that there will be a positive relationship between the various measures of the quality of corporate governance and the fees paid to the external auditor.

\section{Other Control Variables}

Other control variables were included in the model of audit fees based on the results of prior research, including the following:

\footnotetext{
${ }^{12}$ In the Belgian context, independent directors are directors that are independent from both management and the majority shareholders (blockholders). Non-executive directors are director that do not hold an executive position in the company. Hence, non-executive directors could well be non-independent from the majority shareholders.
} 
LNASSET Natural log of total assets.

SUB Number of subsidiaries controlled by the company subject to audit.

We also considered including a dummy variable indicating the existence of MAS services provided by the audit firm. This variable was not significant in any of our analyses and has been dropped from the results reported in the paper.

\section{$\underline{\text { Data }}$}

The population we start from consists of all Belgian companies that meet both of the following criteria: a) being listed on the Brussels Stock exchange in the year 2001, and b) belonging to one of the following industries: manufacturing, technology, retail, distribution and media. ${ }^{13}$ Thus, we deliberately exclude companies from the financial industry, as well as energy and holding companies. Companies in these omitted sectors have very different businesses and balance sheets, and are often much more regulated; so they are likely to behave differently from industrials and non-financial service companies. This restriction reduces our population from 153 to 64 companies.

Since audit fee information is not publicly available in Belgium, we contacted each company in our sample of industrials and non-financial service companies and asked to disclose the total fee paid for the statutory audit of the 2001 accounts. We also inquired about information regarding corporate governance practices within the firm. A copy of the questions included in this survey is provided in Appendix 1. Out of 64 companies that were contacted, 50 provided the required information. We then hand-collected our risk and risk management data from the 2001 annual reports of the 50 remaining fee-disclosing companies in our sample by completing the

\footnotetext{
${ }^{13}$ Note that 153 companies were listed on the Brussels Stock Exchange in 2001.
} 
risk disclosure grid attached in Appendix 2. Note that the financial statement data needed to measure the control variables in our fee model were collected from the Belfirst database.

\section{Estimation Models}

To test our hypotheses, we estimate three models using OLS regression in order to examine the separate effects of risk management and governance on audit fees. We also examine their joint effect in the third model.

\section{Model 1:}

LNFEE $=\mathrm{f}($ Risk Response Variables, LNASSET, SUB, NETINC, RECTA)

\section{Model Type 2:}

LNFEE $=f($ Governance Variables, LNASSET, SUB, NETINC, RECTA $)$

\section{Model Type 3:}

\section{LNFEE $=\mathrm{f}($ Risk Response Variables, Governance Variables, LNASSET, SUB, NETINC, RECTA)}

\section{Results}

\section{Descriptive Statistics}

Table 2 presents descriptive statistics for all variables examined in this paper. The range of companies in the sample is quite broad. Company size varies from a minimum of 13.05 million Euros to a maximum of 12,085.82 million Euros, with a mean of 1,289.17 Euros. The average company possesses 33 subsidiaries. Additionally, the average audit fee for the companies in the sample is $€ 368,049$, with a minimum of $€ 7,987$ and a maximum of $€ 4,675,756$. 
Of most interest to this study are the risk and governance variables. We include two standard risk measures in our analysis: Receivables (RECTA) average about $25 \%$ of total assets with a range of $1.42 \%$ to $63.87 \%$, while net income (NETINC) ranges from negative $€ 288,000$ to $€ 698,000$, with an average of $€ 28,845$. The risk disclosure scores reveal a large variance in the information about risk and risk management reported in company financial statements. Standardized scores for risk range from a high of .294 for compliance risk, followed by .275 for internal process risk, to a low of .0347 for technology risk and .088 for change management risk. These scores indicate that the companies in the sample disclose approximately $29 \%$ of the maximum amount of information about compliance risk but only $3.5 \%$ of the maximum amount of information about technology risk. Of interest is the fact that the disclosure of financial risk, arguably the area of most concern to the auditor, has a standardized disclosure score of .114.

The governance variables also indicate a large variance across organizations. $77.4 \%$ of the companies utilize a Big 5 auditor and 58.0\% have an internal audit department, but only $5.0 \%$ of the companies use formal models of risk management for developing internal control. Almost $75 \%$ of the companies have an audit committee and $30.8 \%$ have a CEO who is also chairman of the Board. The average Board has 9.29 Directors in total, 6.96 non-executive directors (comprising $73.4 \%$ of the average Board), and 3.61 independent directors (comprising $39.2 \%$ of the Board). The correlation results for all variables in the study are reported in Table 3. Variance inflation factors indicate that there are no concerns about multi-collinearity among the variables in the study.

\footnotetext{
$<<<<$ Insert Tables 2 and 3 about here $>>>>>$
} 


\section{$\underline{\text { Regression Results }}$}

The regression results are reported in Table 4. We report the results of three separate models:

- Model 1: Regression model using only the independent variables that reflect risk (plus control variables).

- Model 2: Regression model using only the independent variables that reflect governance (plus control variables).

- Model 3: Regression model with both the risk and governance variables.

Given that there are a large number of independent variables considered in the study relative to the number of observations that are available, we only report the coefficients for the independent variables that are significant. Variables that were determined to be insignificant were not included in the final model.

$<<<<$ Insert Table 4 about here $\quad>>>>>$

For Model 1, we see that four risk variables are significant. RECTA and NETINC are positive and significant, consistent with our expectations in Hypothesis 1. RISK1 is positive and significant consistent with Hypothesis 2. RISK2 is significant but negative, which is consistent with Hypothesis 2A. RISK3, RISK4, RISK5 and RISK6 are not significant. The three risk variables that are significant and positive support our hypotheses that the greater the sensitivity to risk, the higher the audit fee will be since stakeholders will demand more from the company's external auditor. RISK2 reflects sensitivity to compliance risk and suggests a constraint on decisions that affect audit fees.

Model 2 reports the regression results including only governance variables. We observe that AUDCOM and NONEXECP are significant, and both are positive consistent with Hypothesis 2. This suggests that companies that have audit committees and a higher proportion 
of non-executive Directors have, on average, higher audit fees. The other governance variables do not have significant coefficients, most notably BIG5, INDEP, and CEOCHR. Of most interest, however, is the observation that none of the governance variables have negative coefficients, again providing evidence that improved governance does not affect the production of the audit through a reduction of control or inherent risk, which would then be associated with lower audit fees.

Finally, in Model 3, we include both the risk and the governance variables. These results are perfectly consistent with Models 1 and 2. For the risk and risk response variables, RECTA, NETINC, RISK1 are still positive and significant, while RISK2 is negative and significant. Again, two governance variables are significant-AUDCOM and NONEXECP — and both are positive. The results for model 3 suggest that the overall results are stable in spite of the relatively small sample size. In general, the results support all four hypotheses, indicating that audit fees are a function of two demand drivers: (1) risk and (2) demand for control by stakeholders. There is little or no evidence that audit fees are more accurately modeled using a production perspective, especially in light of the significant positive coefficients for the governance variables. These results support the overall conclusions put forth originally in Hay and Knechel (2004).

\section{$\underline{\text { Supplementary Analysis }}$}

We also constructed and tested two (aggregate) risk management indices, as well as an aggregate governance index. First, we define ICRM as the internal control and risk management index that aggregates the score for voluntary internal control and risk management devices. ICRM is scored on a six point scale, and computed by allocating one point for each "non- 
mandated' (or voluntary) risk management measure (that is, RISK1, RISK2, RISK5, RISK6, RISKMAN and IA) that had a non-zero score. Second, we define MANDIC as the aggregate mandated internal control index. This index is scored on a two point scale by summing the values for RISK3 (compliance risk management) and RISK4 (environmental and health and safety risk management). Third, we define an aggregate governance index, GOV, which is scored on a five point scale; one point was allocated if BIG5 equals one, AUDCOM equals one, CEOCHAIR equals one, INDEP\% larger than 50\% and NONEX\% larger than $50 \%$.

We tested all three models using the aggregate indices instead of individual risk management and/or governance scores. Estimating Model 1 including both risk indices, ICRM and MANDIC, yields a non-significant result for ICRM. This clearly indicates that only financial risk management is significantly associated with audit demand. The result on MANDIC is consistent with the results reported in Table 4 , with a significant negative coefficient $(p=? ? ?)$. Estimating Model 2 including the governance index yields very similar results to what is reported in Table 4, with a very significant and positive coefficient on GOV ( $p=0.0028)$. Finally, estimating Model 3 by including both risk management indices and the governance index, yields an insignificant ICRM coefficient, a negative significant MANDIC coefficient $(p=0.0323)$ and a positive significant GOV coefficient $(\mathrm{p}=0.0008)$. Again, these results are generally consistent with Table 4, but indicate that only financial risk management is positively associated with external audit demand.

\section{Summary and Conclusion}

In this paper we examine the impact of risks and controls in the determination of audit fees. Based on a demand-oriented view on auditing, we hypothesize that there is a positive 
association between internal control / risk management in an organization and its audit fee, and also between corporate governance and audit fee. We argue that such a complementary association is likely in a multiple stakeholder framework where sharing of control costs between stakeholders and positive control externalities amongst stakeholders lead to increased voluntary demand for levels of control. We further argue that external auditing and internal controls are substitutes, however, in case of mandated internal controls, as the latter increase the overall control cost.

Consistent with our expectations, we find for a sample of Belgian listed companies that audit fees are higher when a company has an audit committee, discloses a relatively high level of financial risk management, and has a larger proportion of independent Board Members. Audit fees are lower when a company discloses a relatively high level of compliance risk management. The latter result is however consistent with our hypothesis that the association between internal control and audit fees is negative if internal controls are mandated. In the latter case mandated controls act as substitutes for non-mandated controls. 


\section{References}

Anderson, T. and Zéghal, D., (1994). "The Pricing of Audit Services: Further Evidence from the Canadian Market”, Accounting and Business Research, 24 (Summer):195-207.

Blokdijk, H., F. Drieenhuizen, D. Simunic and M. Stein. "Determinants of the Mix of Audit Procedures: Key Factors that Cause Auditors to Change What They Do". Working Paper, SSRN, 2004.

Carcello, J.V., Hermanson, D.R. Neal, T.L. and Riley, R. R. Jr., (2002). "Board Characteristics and Audit Fees." Contemporary Accounting Research 19 (Fall): 365-384.

Eichenseher, J. W. and Shields, D. (1985). "Corporate Director Liability and Monitoring Preferences". Journal of Accounting and Public Policy 4 (Spring): 13-31.

Eilifsen, A., W.R. Knechel and P. Wallage (2001). "External Assurance Services and Strategic Business Risk: An International Field Study”. Accounting Horizons (September): pp. 193-207.

Hackenbrack, K. and W.R. Knechel. "An Empirical Examination of Time Usage in the Audit Process". Contemporary Accounting Research (Fall 1997).

Hay, D. and W.R. Knechel (2004). "Evidence on the Association among Elements of Control and External Assurance”, Working paper, University of Auckland.

Hay, D., W.R. Knechel and N. Wong (2004). "Audit Fees: A Meta-Analysis of The Effect of Supply And Demand Attributes." Working paper, University of Auckland.

Jensen, K.L. and Payne, J.L. (2003). "Management Tradeoffs of Internal Control and External Auditor Expertise". Auditing: A Journal of Practice and Theory, 22 (September): 99119.

Knechel, W.R (2001). Auditing: Assurance and Risk, $2^{\text {nd }}$ Edition. SouthWestern College Publishing.

Knechel, W.R. (2002). "The Role of the Independent Accountant in Effective Risk Management". Journal of Economics and Management (February).

Newton, J.D. and Ashton R.H., (1989) "The Association Between Audit Report Technology and Audit Delay," Auditing: A Journal of Practice and Theory 8 (supplement): 22-37.

O'Keefe, T., Simunic, D. and Stein, M. (1994). "The production of audit services: Evidence from a major public accounting firm". Journal of Accounting Research 32 (Autumn): 241261. 
O'Sullivan, N., (2000). "The Impact of Board Composition and Ownership on Audit Quality: Evidence from Large UK Companies," British Accounting Review, 32 (December): 397-414.

Pearson, T., and G. Trompeter. 1994. "Competition in the market for audit services: The effect of supplier concentration on audit fees." Contemporary Accounting Research 11 (1): 91114.

Pincus, K., Rusbarsky, M. and Wong, J. 1989. "Voluntary Formation of Corporate Audit Committees Among NASDAQ Firms". Journal of Accounting and Public Policy 8 (Winter) :239-265.

Simunic, D. A., (1980), "The Pricing of Audit Services: Theory and Evidence", Journal of Accounting Research, 18 (Spring): 161-189.

Simunic, D. A. (1984). "Auditing, Consulting, and Auditor Independence". Journal of Accounting Research 22 (Autumn): 679-702.

Stice, J.D. (1991) "Using Financial and Market Information to Identify Pre-Engagement Factors Associated with Lawsuits Against Auditors." Accounting Review 66 (July): 516-534.

Walker, P. L and Casterella, J. R. (2000), "The role of auditee profitability in pricing new audit engagements," Auditing: A Journal of Practice and Theory 19 (Spring): 157 -167.

Wallace, W. A., (1984), "Internal Auditors Can Cut Outside CPA Costs", Harvard Business Review, 62 (March-April): 16, 20. 


\section{FIGURE 1}

\section{Optimal Selection of Controls for a Single Stakeholder}

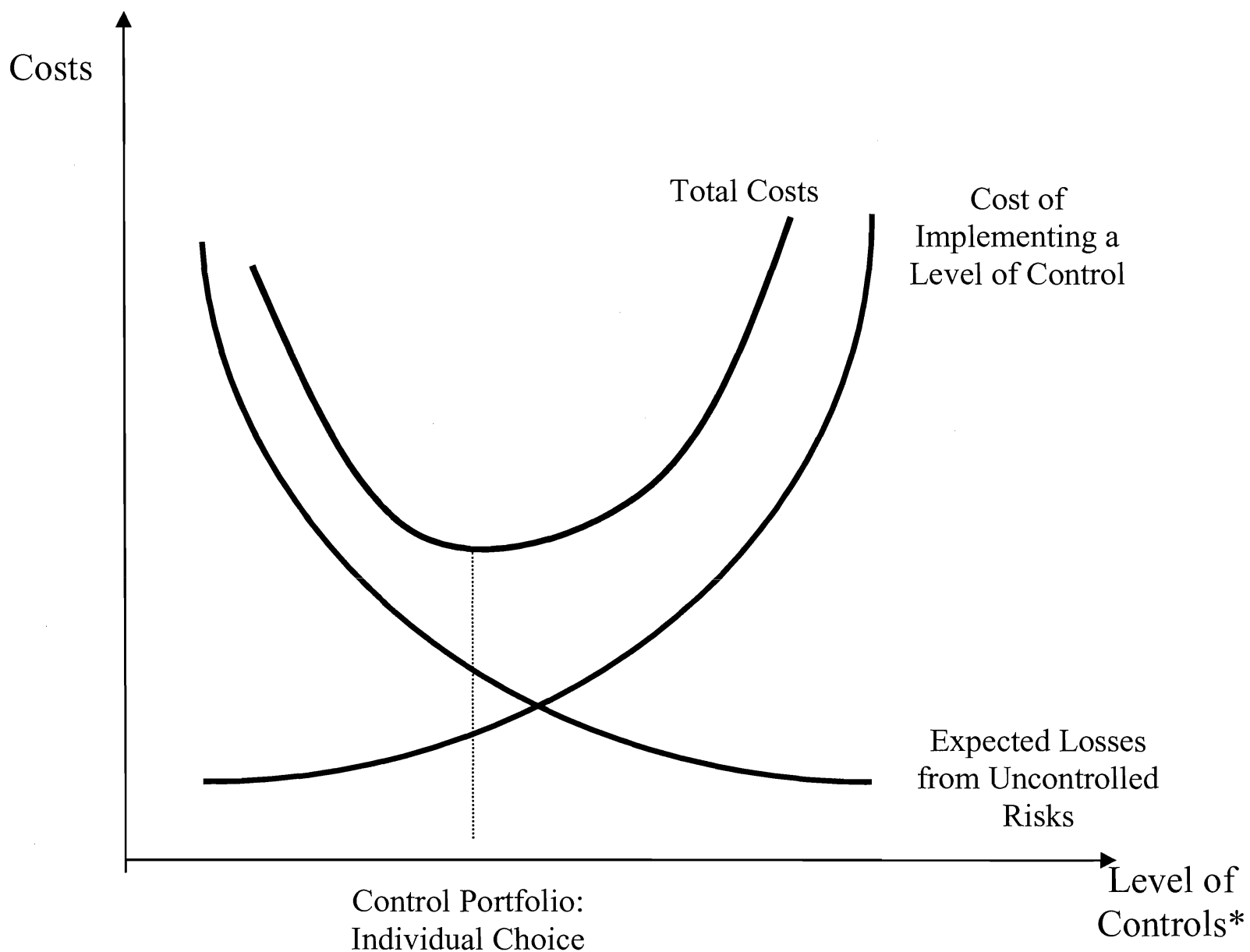

* Note that "level of control" refers to the mapping of specific control selections and related scope of control coverage to a single measure that is monotonically increasing in the control portfolio. 
FIGURE 2

Optimal Selection of Controls for a Single Stakeholder among Multiple Stakeholders:

The Case of External Costs and Benefits

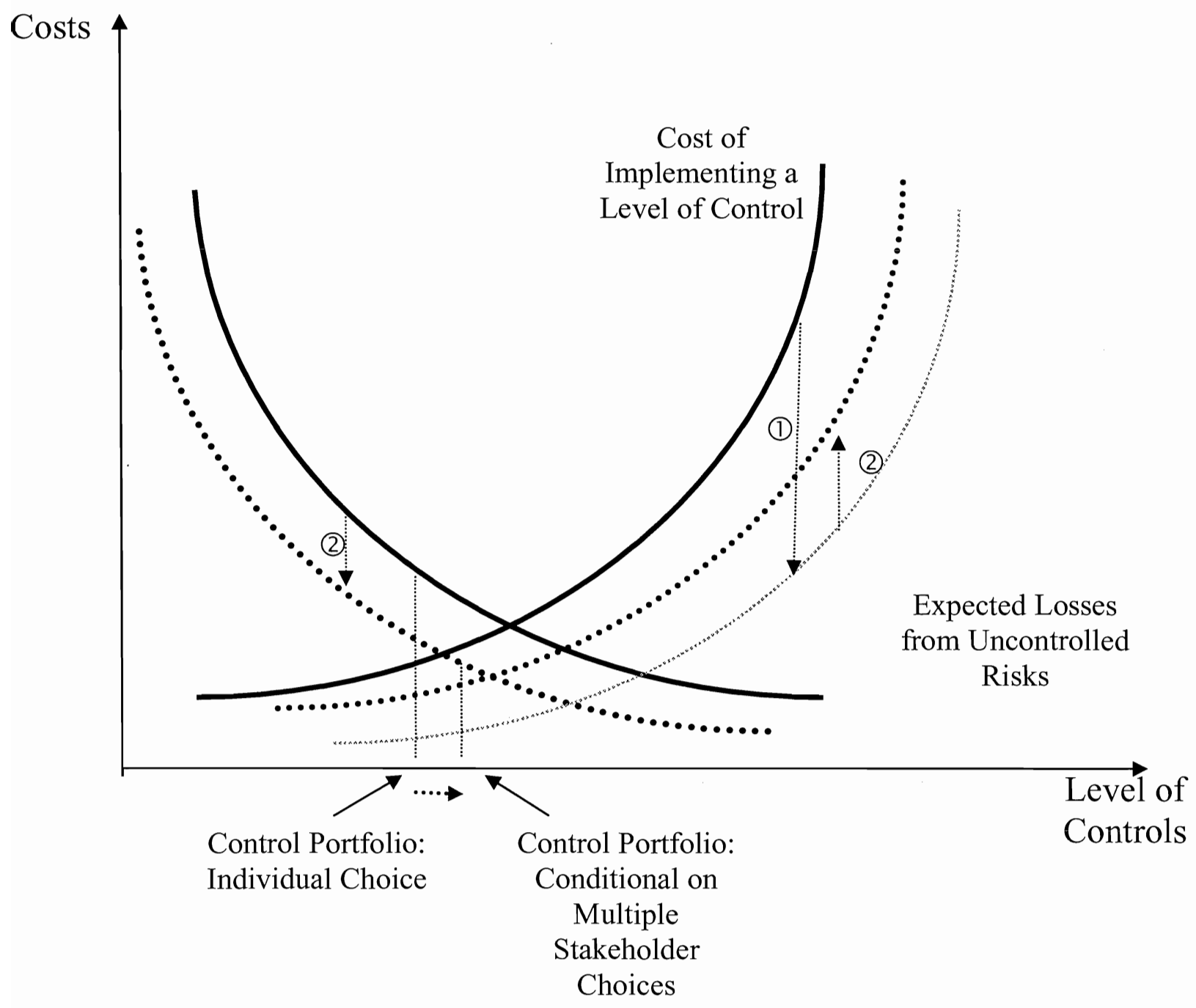




\section{TABLE 1}

\section{Definition of Variables}

\begin{tabular}{|c|c|c|}
\hline Variable & Definition & Expected Sign \\
\hline \multicolumn{3}{|c|}{ Panel A: Risk Variables } \\
\hline NETINC & Net income & \\
\hline RECTA & Ratio of receivables to total assets & + \\
\hline RISK1 & $\begin{array}{l}\text { A score from } 1 \text { to } 5 \text {, scaled by the maximum value } \\
\text { in the sample, reflecting the extent of disclosures } \\
\text { about financial risk and risk management. }\end{array}$ & + \\
\hline RISK2 & $\begin{array}{l}\text { A score from } 1 \text { to } 5 \text {, scaled by the maximum value } \\
\text { in the sample, reflecting the extent of disclosures } \\
\text { about compliance risk and risk management. }\end{array}$ & - \\
\hline RISK3 & $\begin{array}{l}\text { A score from } 1 \text { to } 5 \text {, scaled by the maximum value in } \\
\text { the sample, reflecting the extent of disclosures about } \\
\text { environmental and safety risk and risk management. }\end{array}$ & - \\
\hline RISK4 & $\begin{array}{l}\text { A score from } 1 \text { to } 5 \text {, scaled by the maximum value } \\
\text { in the sample, reflecting the extent of disclosures } \\
\text { about technology risk and risk management. }\end{array}$ & + \\
\hline RISK5 & $\begin{array}{l}\text { A score from } 1 \text { to } 5 \text {, scaled by the maximum value } \\
\text { in the sample, reflecting the extent of disclosures } \\
\text { about internal process risk and risk management. }\end{array}$ & + \\
\hline RISK6 & $\begin{array}{l}\text { A score from } 1 \text { to } 5 \text {, scaled by the maximum value } \\
\text { in the sample, reflecting the extent of disclosures } \\
\text { about change management risk and risk } \\
\text { management. }\end{array}$ & + \\
\hline IA & $\begin{array}{l}\text { Dummy variable }=1 \text { if the company has an internal } \\
\text { audit department, zero otherwise. }\end{array}$ & + \\
\hline RISKMAN & $\begin{array}{l}\text { Dummy variable }=1 \text { if the company uses formal } \\
\text { models of risk management as part of internal } \\
\text { control, zero otherwise. }\end{array}$ & + \\
\hline \multicolumn{3}{|c|}{ Panel B: Governance Variables } \\
\hline BIG5 & $\begin{array}{l}\text { Dummy variable }=1 \text { if audit firm is a Big } 5 \text { firm, } \\
\text { zero otherwise. }\end{array}$ & + \\
\hline AUDCOM & $\begin{array}{l}\text { Dummy variable }=1 \text { if the company has an audit } \\
\text { committee, zero otherwise. }\end{array}$ & + \\
\hline NONEX & $\begin{array}{l}\text { Number of non-executive members of the Board of } \\
\text { Directors. }\end{array}$ & + \\
\hline NONEX\% & $\begin{array}{l}\text { Percentage of the Board of Directors that are } \\
\text { considered to be non-executive directors. }\end{array}$ & + \\
\hline INDEP & $\begin{array}{l}\text { Number of independent members of the Board of } \\
\text { Directors. }\end{array}$ & + \\
\hline INDEP\% & $\begin{array}{l}\text { Percentage of the Board of Directors that are } \\
\text { considered to be independent. }\end{array}$ & + \\
\hline BODNR & Total number of members on the Board of Directors. & + \\
\hline
\end{tabular}




\begin{tabular}{|l|l|c|}
\hline CEOCHR & $\begin{array}{l}\text { Dummy }=1 \text { if the CEO is also the Chairperson of } \\
\text { the Board of Directors, zero otherwise. }\end{array}$ & + \\
\hline Panel C: Control Variables & + \\
\hline LNASSET & Natural log of total assets & + \\
\hline SUB & Number of subsidiaries controlled by the company & + \\
\hline
\end{tabular}


TABLE 2

\section{Descriptive Statistics}

\begin{tabular}{|c|c|c|c|c|}
\hline Variable $(\mathrm{N}=\mathbf{5 0})$ & Mean & Std Deviation & Minimum & Maximum \\
\hline \multicolumn{5}{|l|}{ Dependent Variable } \\
\hline FEE (in Euros) & 368,049 & 836,984 & 7,987 & $4,675,756$ \\
\hline LNFEE & 11.85 & 1.25 & 8.99 & 15.36 \\
\hline \multicolumn{5}{|l|}{ Control Variables: } \\
\hline ASSET (000’s Euros) & $1,289,166$ & $2,787,402$ & 13,053 & $12,085,816$ \\
\hline LNASSET & 12.65 & 1.69 & 9.48 & 16.31 \\
\hline SUB & 33.06 & 26.50 & 1.00 & 95 \\
\hline \multicolumn{5}{|l|}{ Risk Variables: } \\
\hline NETINC (000's Euros) & 28,845 & 125,349 & $-288,000$ & 698,000 \\
\hline RECTA & 0.253 & 0.137 & 0.014 & 0.639 \\
\hline RISK1 & 0.114 & 0.197 & 0 & 1 \\
\hline RISK2 & 0.294 & 0.460 & 0 & 1 \\
\hline RISK3 & 0.133 & 0.232 & 0 & 1 \\
\hline RISK4 & 0.035 & 0.148 & 0 & 1 \\
\hline RISK5 & 0.275 & 0.451 & 0 & 1 \\
\hline RISK6 & 0.088 & 0.217 & 0 & 1 \\
\hline IA & 0.580 & 0.499 & 0 & 1 \\
\hline RISKMAN & 0.118 & 0.325 & 0 & 1 \\
\hline \multicolumn{5}{|l|}{ Governance Variables } \\
\hline BIG5 & 0.774 & 0.423 & 0 & 1 \\
\hline AUDCOM & 0.745 & 0.440 & 0 & 1 \\
\hline NONEX & 6.960 & 3.404 & 0 & 17 \\
\hline NONEX\% & 0.734 & 0.194 & 0 & 1 \\
\hline INDEP & 3.610 & 2.060 & 0 & 12 \\
\hline INDEP\% & 0.392 & 0.171 & 0 & 0.875 \\
\hline BODNR & 9.290 & 3.196 & 4 & 19 \\
\hline CEOCHR & 0.308 & 0.466 & 0 & 1 \\
\hline
\end{tabular}

Note: See Table 1 for variable definitions. 
TABLE 3

\section{Correlations Among the Variables Used in the Analysis}

\begin{tabular}{|c|c|c|c|c|c|c|c|c|c|}
\hline & LNASSET & SUB & NETINC & RECTA & RISK1 & RISK2 & TRISK & RISKMAN & IA \\
\hline LNASSET & 1.000 & $0.680^{* * *}$ & $0.467^{* * *}$ & -0.231 & $0.520^{* * *}$ & $0.251^{\star}$ & $0.39099 * * *$ & $0.366^{* * *}$ & $0.430^{* * *}$ \\
\hline SUB & $0.680 * \star *$ & 1.000 & 0.050 & 0.017 & $0.254^{*}$ & -0.032 & 0.12067 & 0.000 & $0.365^{\star *}$ \\
\hline NETINC & $0.467^{* * *}$ & 0.050 & 1.000 & -0.195 & $0.551^{* \star *}$ & $0.330^{* *}$ & $0.48106^{* * *}$ & $0.505^{* * *}$ & 0.150 \\
\hline RECTA & -0.231 & 0.017 & -0.195 & 1.000 & -0.045 & $-0.248^{*}$ & -0.09464 & -0.009 & -0.089 \\
\hline RISK1 & 0.520 ** & $0.254{ }^{*}$ & $0.551^{* * *}$ & -0.045 & 1.000 & $0.241^{*}$ & $0.46784^{\star \star \star}$ & $0.473^{* * *}$ & $0.393^{* * *}$ \\
\hline RISK2 & $0.251^{*}$ & -0.032 & $0.330^{* *}$ & $-0.248^{*}$ & $0.241^{*}$ & 1.000 & $0.79956 * * *$ & 0.164 & 0.091 \\
\hline TRISK & $0.390 * * *$ & 0.120 & $0.481^{* * *}$ & -0.094 & $0.467^{\star \star \star}$ & $0.799 * \star *$ & 1.00000 & $0.365^{* * *}$ & $0.243^{*}$ \\
\hline RISKMAN & $0.366^{* * *}$ & 0.000 & $0.505^{\star \star *}$ & -0.009 & $0.473^{* * *}$ & 0.164 & $0.36529 * * *$ & 1.000 & 0.197 \\
\hline IA & $0.430 * * *$ & $0.365^{\star *}$ & 0.150 & -0.089 & $0.393^{* * *}$ & 0.091 & $0.24367^{*}$ & 0.197 & 1.000 \\
\hline AUDCOM & 0.187 & $0.249^{*}$ & 0.102 & 0.029 & 0.210 & 0.064 & 0.18066 & -0.061 & $0.327^{\star *}$ \\
\hline CEOCHAIR & -0.167 & -0.004 & -0.182 & 0.190 & -0.155 & 0.055 & 0.08837 & -0.102 & -0.061 \\
\hline INDEP & $0.472^{\star \star *}$ & 0.351 * * & $0.365^{* * *}$ & 0.053 & $0.512^{* \star *}$ & $0.254^{*}$ & 0.37551 *** & $0.330 * *$ & $0.285^{\star *}$ \\
\hline INDEPP & 0.164 & 0.125 & 0.132 & 0.214 & 0.174 & 0.133 & 0.22256 & $0.243^{*}$ & 0.169 \\
\hline NONEXEC & $0.606^{* * *}$ & $0.314^{*}$ & $0.394^{* * *}$ & -0.179 & $0.446^{* * *}$ & 0.161 & $0.24236^{\star}$ & 0.192 & $0.458^{* * *}$ \\
\hline NONEXECP & $0.403^{* * *}$ & 0.217 & $0.247^{\star}$ & -0.001 & 0.150 & 0.083 & 0.13227 & 0.147 & $0.391^{* * *}$ \\
\hline BIG5 & $0.302^{* *}$ & $0.306^{* *}$ & 0.099 & $0.254^{*}$ & $0.256^{*}$ & 0.129 & $0.24483^{*}$ & 0.043 & 0.232 \\
\hline LNBODNR & $0.514^{* * *}$ & $0.328^{* *}$ & $0.314^{* *}$ & $-0.259^{*}$ & $0.453^{* * *}$ & 0.157 & 0.21480 & 0.102 & $0.311^{* * *}$ \\
\hline TGOV & $0.539 * * *$ & $0.364^{* *}$ & $0.290^{* *}$ & 0.006 & $0.483^{* \star *}$ & 0.158 & $0.30199^{* *}$ & $0.402^{* *}$ & $0.710^{* * *}$ \\
\hline
\end{tabular}




\begin{tabular}{|c|c|c|c|c|c|c|c|c|c|}
\hline & AUDCOM & CEOCHAIR & INDEP & INDEPP & NONEXEC & NONEXECP & BIG5 & LNBODNR & TGOV \\
\hline LNASSET & 0.187 & -0.167 & $0.472^{* *}$ & 0.164 & $0.606^{* * *}$ & $0.403^{* * *}$ & $0.302^{\star *}$ & $0.514^{* * *}$ & $\odot .539 * * *$ \\
\hline SUB & 0.249 * & -0.004 & 0.351 ** & 0.125 & $0.314^{* *}$ & 0.217 & $0.306^{* *}$ & $0.328^{* *}$ & $0.364 * *$ \\
\hline NETINC & 0.102 & -0.182 & $0.365^{* * *}$ & 0.132 & $0.394 * * *$ & $0.247^{*}$ & 0.099 & $0.314 * *$ & 0.290 ** \\
\hline RECTA & 0.029 & 0.190 & 0.053 & 0.214 & -0.179 & -0.001 & 0.254 & -0.259 & 0.006 \\
\hline RECTA & $0: 83$ & 0.180 & 0.711 & 0.134 & 0.218 & 0.994 & 0.071 * & 0.068 * & 0.963 \\
\hline NRISK3 & 0.210 & -0.155 & $0.512^{* * *}$ & 0.174 & $0.446^{* * *}$ & 0.150 & $0.256^{*}$ & $0.453^{* * *}$ & 0.483 \\
\hline NRISK4 & 0.064 & 0.055 & $0.254^{*}$ & 0.133 & 0.161 & 0.083 & 0.129 & 0.157 & 0.158 \\
\hline TNRISK & 0.180 & 0.088 & $0.375^{* * *}$ & 0.222 & $0.242^{*}$ & 0.132 & 0.244 & 0.214 & 0.301 \\
\hline DRISK1 & -0.061 & -0.102 & $0.330^{* *}$ & $0.243^{*}$ & 0.192 & 0.147 & $0.043^{* *}$ & 0.102 & 0.402 \\
\hline IA & $0.327^{* *}$ & -0.061 & $0.285^{\text {** }}$ & 0.169 & $0.458^{* * *}$ & $0.391^{* * *}$ & 0.232 & $0.311^{* *}$ & $0.710^{* * *}$ \\
\hline AUDCOM & 1.000 & -0.186 & $0.262^{*}$ & 0.179 & $0.317^{* *}$ & 0.210 & $0.240^{*}$ & $0.285^{* *}$ & $0.564^{* * *}$ \\
\hline CEOCHAIR & -0.186 & 1.000 & -0.035 & 0.118 & $-0.238^{*}$ & -0.165 & 0.039 & -0.195 & $-0.457^{\star \star *}$ \\
\hline INDEP & $0.262^{*}$ & -0.035 & 1.000 & $0.810 * * *$ & $0.467^{* * *}$ & $0.273^{*}$ & 0.203 & $0.482^{* * *}$ & $0.513^{* * *}$ \\
\hline INDEPP & 0.179 & 0.118 & $0.810^{* * *}$ & 1.000 & 0.065 & 0.232 & 0.129 & 0.015 & $0.352^{* *}$ \\
\hline NONEXEC & $0.317^{* *}$ & $-0.238^{*}$ & $0.467^{* * *}$ & 0.065 & 1.000 & $0.647^{* * *}$ & 0.222 & $0.810^{* * *}$ & $0.592^{* * *}$ \\
\hline NONEXECP & 0.210 & -0.165 & $0.273^{*}$ & 0.232 & 0.647 & 1.000 & 0.167 & 0.145 & $0.569^{* * *}$ \\
\hline BIG5 & $0.240^{*}$ & 0.039 & 0.203 & 0.129 & 0.222 & 0.167 & 1.000 & 0.135 & $0.436^{* * *}$ \\
\hline LNBODNR & $0.285^{* *}$ & -0.195 & $0.482^{* * *}$ & 0.015 & $0.810^{* * *}$ & 0.145 & 0.135 & 1.000 & $0.378^{* * *}$ \\
\hline TGOV & $0.564^{* * *}$ & $-0.457^{* \star *}$ & $0.513^{* * *}$ & $0.352^{* *}$ & $0.592^{* * *}$ & $0.569^{* * *}$ & $0.436^{* * *}$ & $0.378^{* * *}$ & 1.000 \\
\hline
\end{tabular}


TABLE 4

\section{OLS Regression Results}

\begin{tabular}{|c|c|c|c|c|}
\hline & $\begin{array}{l}\text { Predicted } \\
\text { sign }\end{array}$ & $\begin{array}{l}\text { Model } 1 \\
(\mathrm{~N}=49)\end{array}$ & $\begin{array}{l}\text { Model } 2 \\
(\mathrm{~N}=48)\end{array}$ & $\begin{array}{l}\text { Model } 3 \\
(\mathrm{~N}=47)\end{array}$ \\
\hline Intercept & & $\begin{array}{c}6.642 \\
(<0.001)\end{array}$ & $\begin{array}{c}4.706 \\
(0.001)\end{array}$ & $\begin{array}{c}5.368 \\
(<0.001)\end{array}$ \\
\hline \multicolumn{5}{|c|}{ Control Variables } \\
\hline LNASSET & + & $\begin{array}{c}0.333 \\
(0.002)\end{array}$ & $\begin{array}{c}0.406 \\
(0.001)\end{array}$ & $\begin{array}{c}0.344 \\
(0.002)\end{array}$ \\
\hline SUB & + & $\begin{array}{c}0.014 \\
(0.010)\end{array}$ & $\begin{array}{c}0.010 \\
(0.081)\end{array}$ & $\begin{array}{c}0.011 \\
(0.041)\end{array}$ \\
\hline \multicolumn{5}{|l|}{ Risk Variables } \\
\hline NETINC & + & $\begin{array}{c}0.00000284 \\
(0.007)\end{array}$ & $\begin{array}{c}0.00000235 \\
(0.016)\end{array}$ & $\begin{array}{c}0.00000226 \\
(0.015)\end{array}$ \\
\hline RECTA & + & $\begin{array}{c}1.82233 \\
(0.022)\end{array}$ & $\begin{array}{l}1.74174 \\
(0.018)\end{array}$ & $\begin{array}{l}1.53725 \\
(0.026)\end{array}$ \\
\hline RISK1 & + & $\begin{array}{c}1.654 \\
(0.031)\end{array}$ & & $\begin{array}{c}1.439 \\
(0.038)\end{array}$ \\
\hline RISK2 & - & $\begin{array}{l}-0.516 \\
(0.029)\end{array}$ & & $\begin{array}{l}-0.467 \\
(0.025)\end{array}$ \\
\hline \multicolumn{5}{|c|}{ Governance Variables } \\
\hline AUDCOM & + & & $\begin{array}{c}0.552 \\
(0.0176)\end{array}$ & $\begin{array}{c}0.493 \\
(0.0238)\end{array}$ \\
\hline NONEXP & + & & $\begin{array}{c}1.092 \\
(0.0994)\end{array}$ & $\begin{array}{c}1.322 \\
(0.0364)\end{array}$ \\
\hline F-value & & $\begin{array}{c}21.95 \\
(<0.001)\end{array}$ & $\begin{array}{c}25.28 \\
(<0.001)\end{array}$ & $\begin{array}{c}24.14 \\
(<0.001)\end{array}$ \\
\hline Adj. R-square & & $72.37 \%$ & $75.61 \%$ & $80.10 \%$ \\
\hline
\end{tabular}

Notes: See Table 1 for variable definitions. p-values indicated with parentheses 
